CLINICAL STUDY

\title{
Thyrotropin, but not a polymorphism in type II deiodinase, predicts response to paroxetine in major depression
}

\author{
Jantien P Brouwer ${ }^{1}$, Bente C Appelhof ${ }^{1}$, Robin P Peeters ${ }^{4}$, Witte J G Hoogendijk ${ }^{5}$, Jochanan Huyser ${ }^{2}$, \\ Aart H Schene ${ }^{2}$, Jan G P Tijssen ${ }^{3}$, Richard Van Dyck ${ }^{5}$, Theo J Visser ${ }^{4}$, Wilmar M Wiersinga ${ }^{1}$ and Eric Fliers ${ }^{1}$ \\ Departments of ${ }^{1}$ Endocrinology, ${ }^{2}$ Psychiatry and ${ }^{3}$ Cardiology, Academic Medical Center, Meibergdreef 9, 1101, Amsterdam, The Netherlands, \\ ${ }^{4}$ Department of Internal Medicine, Erasmus University Medical Center, Rotterdam, The Netherlands and ${ }^{5}$ Department of Psychiatry, Vrije Universiteit \\ Medical Center, Amsterdam, The Netherlands. \\ (Correspondence should be addressed to J P Brouwer; Email: j.p.brouwer@amc.uva.nl)
}

\begin{abstract}
Objective: The determinants of response to antidepressant treatment in major depression are unknown at present. The aim of the present study was to establish whether response is predicted by Hypothalamus-Pituitary-Thyroid (HPT) axis parameters or by a recently discovered polymorphism in the enzyme type II deiodinase (DII), which catalyzes the production of $\mathrm{T}_{3}$ in the brain.

Design: We analyzed prediction of response to paroxetine treatment by calculating response rates per tertile of HPT-axis parameters and per DII genotype.

Methods: Ninety-eight outpatients with major depression (DSM-IV) were included. Serum concentrations of TSH, $\mathrm{FT}_{4}$ and delta TSH in a DEX/CRH-TRH test were measured. In addition, the presence of a polymorphism in the DII sequence (Thr92Ala) was determined.

Results: The overall treatment response was 48 of 98 patients (49\%). After exclusion of patients with subclinical hypothyroidism and/or TPO antibodies $(n=16)$, higher serum TSH significantly predicted response (response rate per tertile from low to high TSH: 36\%, 42\%, and 67\%). Heterozygous patients for the DII polymorphism $(44 \%)$ had slightly lower serum TSH $(P=0.03)$ as compared to patients with the wild-type DII (47\%). The polymorphism was unrelated to treatment response.

Conclusion: Higher serum TSH was associated with response to paroxetine in patients with major depression.
\end{abstract}

European Journal of Endocrinology 154 819-825

\section{Introduction}

Treatment of major depressive disorder with a first trial of antidepressant therapy is only effective in $60-70 \%$ of patients (1). The determinants of treatment response are not well known. In depression, changes have been described in the Hypothalamic-Pituitary-Thyroid (HPT) axis, such as a lower serum thyrotropin (TSH) and a higher serum-free thyroxin $\left(\mathrm{FT}_{4}\right)$, but no change in serum tri-iodothyronine $\left(\mathrm{T}_{3}\right)$ concentrations. Furthermore, the presence of thyroid peroxidase (TPO) auto-antibodies and subclinical hypothyroidism have been reported to be associated with major depression $(2,3)$. In dynamic tests, the delta TSH to thyrotropinreleasing hormone (TRH) is blunted in some $25 \%$ of depressed patients $(4,5)$.

These changes may be of clinical significance, since they have been related to response by some $(6,7)$ but not all authors (8). So far, the nature of a relation between thyroid function and response seems unclear; Duval et al. (6) described higher evening TSH concentrations in treatment responders, while Sullivan et al. (7) found that non-response was predicted by a high delta TSH in the TRH test. However, most studies were retrospective and included only small groups of patients $(6,9-12)$. Furthermore, no studies so far included TPO antibodies in their analysis, although thyroid autoimmunity is an important determinant of TSH levels (13) or may be a predictor of response itself. These factors may explain the different outcomes of these studies.

Given these HPT-axis aberrations the response to antidepressant treatment may also be associated with polymorphisms in genes involved in this axis. The local production of $\mathrm{T}_{3}$ from $\mathrm{T}_{4}$ in the brain is determined to a large extent by the enzyme type II deiodinase (DII) (14). The activity of DII in rat brain is increased by antidepressants of various classes, including selective 
serotonin reuptake inhibitors (SSRIs) (15-17). Since $\mathrm{T}_{3}$ increases the availability of serotonin in the frontal cortex (18), DII may modulate the antidepressant effect of SSRIs. The DII enzyme plays a role in the anterior pituitary as well, where it mediates the negative feedback of $\mathrm{T}_{4}$ on TSH secretion (19). Recently, an A/G polymorphism was identified at position 674 of the DII sequence, leading to a change in amino acids (Thr92Ala). This polymorphism was found to be associated with serum TSH concentration and insulin resistance $(20,21)$.

We hypothesized that baseline thyroid function (TSH, delta $\mathrm{TSH}$ and $\mathrm{FT}_{4}$ ) and/or the DII polymorphism predict response to an SSRI. We tested this hypothesis in patients with major depression, who participated in a randomized clinical trial addressing the efficacy of $\mathrm{T}_{3}$ addition to paroxetine. As the response rate in the trial was exactly similar in $\mathrm{T}_{3}$ addition as in placebo addition groups (22), we regarded this as a paroxetine alone treated group. Nevertheless, to be sure that $\mathrm{T}_{3}$ addition was not a determinant of treatment response, results were corrected for $\mathrm{T}_{3}$ treatment.

\section{Subjects and methods}

\section{Subjects}

The depressed patients took part in a randomized clinical trial evaluating the efficacy of thyroid hormone $\left(\mathrm{T}_{3}\right)$ addition to treatment with an SSRI, as described elsewhere (22). To be eligible for the study patients had to be between 18 and 65 years of age, to be free of antidepressant medication for at least 3 months and to fulfil the diagnostic criteria for major depressive disorder according to the fourth edition of diagnostic and statistical manual of mental disorders (DSM-IV) (23). Patients were required to have a score of at least 16 on the 17-item Hamilton Rating Scale for Depression (HRSD), a commonly used questionnaire to rate depression severity.

Exclusion criteria were bipolar disorder, substance abuse or dependence disorder for alcohol or drugs, clinically manifest thyroid or adrenocortical disease. Patients were not allowed to have taken corticosteroids or drugs interfering with thyroid hormone metabolism (e.g. amiodarone), thyroid hormone, or any psychotropic drug during the last 3 months before inclusion, with the exception of a low dose benzodiazepine (equivalent to $30 \mathrm{mg}$ oxazepam daily). To obtain accurate measurement of treatment response, patients were only included when they had taken study medication for at least 6 weeks. All randomized patients provided written informed consent and the study was approved by the medical ethical committee of the Academic Medical Center and the Free University Medical Center.

\section{Medication schedule and psychiatric outcome measures}

After the measurements of endocrine parameters, patients were randomly assigned to study treatment comprising three groups: placebo, $25 \mu \mathrm{g} \mathrm{T}$ or $50 \mu \mathrm{g} \mathrm{T}_{3}$ in a ratio of 2: 1: 1 respectively. This double-blinded study medication was given in addition to open label antidepressant treatment with $30 \mathrm{mg}$ paroxetine. In total patients were treated for 8 weeks. Ratings of HRSD were obtained every 2 weeks and a physician (B.C.A and J.P.B) monitored compliance. Primary outcome was the score on the 17-item HRSD at 8 weeks or the last HRSDscore obtained. Response was defined as $\geq 50 \%$ reduction in HRSD score from baseline to week 8 .

\section{Procedures, hormone measurements and DII polymorphism analyses}

Subjects had an intravenous puncture for blood withdrawal in the morning (before $1000 \mathrm{~h}$ ) to determine baseline levels of serum TSH, $\mathrm{FT}_{4}$, TPO antibodies and isolation of DNA. A DEX/CRH test was performed as described by Heuser et al. (24) with the addition of a TRH stimulation test (DEX/CRH-TRH test). Because dexamethasone suppresses TSH, a dose of $400 \mu \mathrm{g} \mathrm{TRH}$ (as was used by others $(7 ; 11 ; 25 ; 26)$ ) was chosen. At the day prior to the test, subjects took a tablet of $1.5 \mathrm{mg}$ dexamethasone at $2300 \mathrm{~h}$. On the day of the test, an intravenous catheter was inserted at $1400 \mathrm{~h}$. From $1445 \mathrm{~h}$ until $1630 \mathrm{~h}$ blood samples were taken every $15 \mathrm{~min}$ for the assessment of serum TSH. At $1500 \mathrm{~h}$, $100 \mu \mathrm{g}$ CRH (Ferring Hoofddorp, Holland) was injected, followed directly by $400 \mu \mathrm{g}$ TRH (Protirelin, Hoechst AG, Frankfurt am Main, Germany). Delta TSH was calculated by subtracting the value before injection from the maximal value after injection of TRH.

Sera were kept at $-20{ }^{\circ} \mathrm{C}$. Hormone assays were conducted in the Endocrinology Laboratory of the Academic Medical Center in Amsterdam. Free $\mathrm{T}_{4}$ and TSH were measured by time-resolved fluoroimmunoassay (Delfia $\mathrm{FT}_{4}$ and hTSH Ultra respectively Wallac Oy, Turku, Finland), with a detection limit of $2 \mathrm{pmol} / \mathrm{l}$ and $0.01 \mathrm{mU} / \mathrm{l}$ respectively. The intra-assay coefficient of variation was $4-6 \%$ and $1-2 \%$; the inter-assay coefficient of variation was $5-8 \%$ and $3-4 \%$ respectively. The reference value for serum $\mathrm{TSH}$ was $0.40-4.00 \mathrm{mU} / \mathrm{l}(27)$ and for $\mathrm{FT}_{4} 10-23 \mathrm{pmol} / \mathrm{l}$. Subclinical hypothyroidism was defined as an increased serum TSH and a normal serum $\mathrm{FT}_{4}$. Anti-TPO was measured by chemiluminescence immunoassay (LUMItest anti-TPO, BRAHMS, Berlin, Germany) with a detection limit of $30 \mathrm{kU} / \mathrm{l}$. The intra-assay coefficient of variation was 3-7\%; the inter-assay coefficient of variation was $8-12 \%$. The cut-off value for a positive anti-TPO titer was $60 \mathrm{kU} / \mathrm{l}$. DNA was extracted from $7 \mathrm{ml}$ of blood using a phenol/chloroform extraction method. After isolation of all DNA samples, a restriction 
fragment length polymorphism (RFLP) analysis was performed twice for every patient as described earlier (21).

\section{Data analysis}

To compare response rates between the three treatment arms, we performed a Pearson Chi-square test. For the prediction of response, we used the following endocrine parameters: baseline serum concentrations of $\mathrm{TSH}, \mathrm{FT}_{4}$, delta TSH (maximal minus baseline TSH) and the fold increase of TSH (maximal divided by baseline TSH) in the DEX/CRH-TRH test. We divided the patients over three equal groups (tertiles) of these parameters. For each parameter the mean decrease in HRSD score and response rates per tertile were calculated. To determine if response rates were significantly different, the chance on response (named relative response rate) with 95\% confidence intervals were calculated for the two higher tertiles relative to the low tertile. We investigated whether the relation between baseline TSH and the response rate was due to $\mathrm{T}_{3}$ treatment or influenced by TPO antibodies, by a logistic regression (method: enter) with response as the dependent variable. For the analysis of response prediction by the DII polymorphism, we calculated response rates and relative response rates with 95\% confidence intervals (CI) per genotype. For the comparison of HPT-axis parameters in the DII genotypes, ANOVA tests with post hoc analyses were performed. Serum TSH and delta TSH were first logtransformed to normalize the distribution. For all tests a $P$ value of $\leq 0.05$ was considered statistically significant and all tests were two-tailed.

The statistical analysis was conceived and supervised by co-author J.G.P. Tijssen, Professor of Clinical Epidemiology and Biostatistics at the Academic Medical Center in Amsterdam.

\section{Results}

\section{Clinical characteristics}

A total of 113 patients with depression met the criteria for eligibility and 98 patients completed 8 weeks of study medication, except for one, who completed 6 weeks. The overall response rate, defined as a $50 \%$ reduction in HRSD score, was 48 of 98 patients (49\%). Response rates in the three treatment arms (placebo, $\left.25 \mu \mathrm{g} \mathrm{T}, 50 \mu \mathrm{g} \mathrm{T}_{3}\right)$ were similar $(50 \%, 46 \%, 50 \%$ respectively; $\left.\chi^{2}: 0.11, \mathrm{df}=2, P=0.95\right)$. Characteristics of responders and non-responders were not statistically different between responders and non-responders (Table 1). The 17-item HRSD scores indicate that the majority of patients had a moderately severe depression and that quite a large proportion of subjects with recurrent $(43 \%)$, chronic (52\%) and therapy resistant $(38 \%)$ depression were included.
Table 1 Clinical characteristics.

\begin{tabular}{lcc}
\hline & $\begin{array}{c}\text { Non-responders } \\
n=50\end{array}$ & $\begin{array}{c}\text { Responders } \\
n=48\end{array}$ \\
\hline Age (mean \pm s.D.) & $46 \pm 11$ & $47 \pm 12$ \\
Woman $(n, \%)$ & $31(62 \%)$ & $32(67 \%)$ \\
17-HRSD (mean \pm s.D.) & $20 \pm 3$ & $21 \pm 3$ \\
Chronic depression $(n, \%)$ & $20(40 \%)$ & $22(46 \%)$ \\
Recurrent depression $(n, \%)$ & $26(52 \%)$ & $25(52 \%)$ \\
Therapy resistant ${ }^{*}(n, \%)$ & $19(38 \%)$ & $17(35 \%)$ \\
\hline
\end{tabular}

*Therapy resistance was defined as having a score of 1 or more in the Thase and Rush classification for therapy resistance (39).

\section{Prediction of treatment response by HPT-axis parameters}

The response rates per tertile of each endocrine parameter are presented in Table 2. There was a trend towards increased treatment response in tertiles with higher serum TSH-values (response per tertile from low to high TSH: $37 \%, 51 \%, 58 \%)$. The relative response rate (RR) as compared to the low tertile was 1.4 (CI 0.79-2.48) in the middle tertile and 1.57 (CI: 0.88$2.74)$ in the high tertile. There was no difference in response rates between the tertiles of serum $\mathrm{FT}_{4}$, delta TSH, nor in the fold increase of TSH. The prevalence of patients with positive TPO-antibodies $(n=9)$ and subclinical hypothyroidism $(n=10)$ was too low to be analyzed as separate determinants of response.

The slightly positive relation between tertiles of TSH and treatment response was corrected for $\mathrm{T}_{3}$ treatment in a logistic regression model. $\mathrm{T}_{3}$ treatment appeared not to affect the trend between TSH and response (before correction: $\mathrm{OR}=1.53$, CI: $0.92-2.53$ and after correction: $\mathrm{OR}=1.52$, CI: $0.92-2.53$ ). However, after additional correction for TPO antibodies, the association between TSH and response rather strengthened (before correction: $\mathrm{OR}=1.53$, CI: $0.92-2.53$ and after correction: $\mathrm{OR}=1.63$, CI: $0.96-2.74$ ). To further exclude the possibility that $\mathrm{T}_{3}$ addition was beneficial in patients with subclinical thyroid disease and thereby caused the association between TSH and response rate, we reanalyzed the data after exclusion of patients with subclinical hypothyroidism and/or positive TPO antibodies. The association in the remaining 82 patients was now statistically significant in the high TSH-tertile (1.87; CI 1.07-3.26; Table 3). This appeared to be mainly due to the exclusion of patients with TPO antibodies, since the mere exclusion of patients with TPO antibodies resulted in a significant association (RR in the high TSH-tertile: 1.81, CI 1.03-3.17), while exclusion of patients with subclinical hypothyroidism did not $(R R=1.62$, CI $0.93-2.81)$. Free $\mathrm{T}_{4}$ nor delta TSH or the fold increase in TSH (response rate from low to high tertile: $59 \%, 36 \%$ and $52 \%$ ) revealed any trend towards the prediction of response after exclusion of patients with positive TPO antibodies and/or subclinical hypothyroidism. 
Table 2 Treatment response per tertile of HPT-axis parameters.

\begin{tabular}{|c|c|c|c|c|c|c|c|c|}
\hline & & $N$ & $\begin{array}{l}\text { Value of } \\
\text { parameter } \\
\text { median } \\
\text { (range) }\end{array}$ & $\begin{array}{c}\text { HRSD at } \\
\text { baseline } \\
\text { (mean } \pm \text { s.D.) }\end{array}$ & $\begin{array}{c}\text { Decrease in } \\
\text { HRSD } \\
\text { (mean } \pm \text { S.D.) }\end{array}$ & $\begin{array}{l}\text { Response } \\
\text { rate } n(\%)\end{array}$ & $\begin{array}{l}\text { Relative } \\
\text { response } \\
\text { rate }\end{array}$ & $95 \% \mathrm{Cl}$ \\
\hline \multirow[t]{3}{*}{ Serum TSH ${ }^{a} \mathrm{mU} / \mathrm{l}$} & low & 30 & $1.20(0.49-1.50)$ & $20 \pm 3$ & $7 \pm 6$ & $11(37 \%)$ & 1.00 & \\
\hline & middle & 35 & $1.90(1.60-2.30)$ & $22 \pm 4$ & $10 \pm 6$ & $18(51 \%)$ & 1.40 & $0.79-2.48$ \\
\hline & high & 33 & $2.80(2.40-9.50)$ & $21 \pm 3$ & $11 \pm 6$ & $19(58 \%)$ & 1.57 & $0.88-2.74$ \\
\hline \multirow[t]{3}{*}{ Serum $\mathrm{FT}_{4}{ }^{\mathrm{a}} \mathrm{pmol} / \mathrm{l}$} & low & 34 & $11.7(9.2-12.5)$ & $21 \pm 3$ & $10 \pm 6$ & $17(50 \%)$ & 1.00 & \\
\hline & middle & 31 & $13.6(12.6-14.6)$ & $21 \pm 3$ & $11 \pm 6$ & $20(65 \%)$ & 1.24 & $0.84-2.30$ \\
\hline & high & 33 & $15.9(15.0-18.7)$ & $21 \pm 4$ & $7 \pm 6$ & $11(33 \%)$ & 0.67 & $0.37-1.20$ \\
\hline \multirow{3}{*}{ Delta $\mathrm{TSH}^{\mathrm{b}} \mathrm{mU} / \mathrm{l}$} & low & 32 & $7.12(1.52-9.27)$ & $20 \pm 3$ & $9 \pm 7$ & $17(53 \%)$ & 1.00 & \\
\hline & middle & 33 & $11.52(9.33-14.23)$ & $21 \pm 3$ & $9 \pm 6$ & $14(42 \%)$ & 0.80 & $0.48-1.37$ \\
\hline & high & 33 & $18.70(14.73-108.50)$ & 50) $21 \pm 3$ & $10 \pm 7$ & $17(52 \%)$ & 0.97 & $0.61-1.54$ \\
\hline
\end{tabular}

Per HPT-axis parameter, patients $(n=98)$ are divided in three equal groups (tertiles). Response rates are shown per tertile.

${ }^{a}$ Morning hormone values measured before dexamethasone ingestion.

${ }^{b}$ The absolute increase in TSH concentration after i.v. injection of $400 \mu \mathrm{g}$ TRH and $100 \mu \mathrm{g} \mathrm{CRH}$. Patients had ingested $1.5 \mathrm{mg}$ dexamethasone the evening before testing (modified DEX/CRH test, Heuser et al. (24)).

\section{Characteristics and treatment response according to DII polymorphism}

The presence of the DII polymorphism was determined in 93 patients. In these patients, $44(47 \%)$ had the AA genotype, 41 (44\%) were heterozygous and 8 (9\%) were homozygous for the $\mathrm{G}$ allele. The clinical and endocrine characteristics of the patients with these genotypes are presented in Table 4. Age, gender, HRSD score at baseline, the course of the depression and the presence of previous therapy resistance were similar in the three groups. Interestingly, there were differences between the groups in serum TSH and delta TSH $(\mathrm{F}=4.00, \mathrm{df}=2$, $90, P=0.02$ and $\mathrm{F}=3.08, \mathrm{df}=2,90, P=0.05$ respectively), but not in the fold increase of TSH $(\mathrm{F}=1.23, \mathrm{df}=$ 2, 90, $P=0.30$ ). Post-hoc analysis revealed that both serum TSH and delta TSH were significantly lower in the heterozygous group as compared to the AAgenotype. After exclusion of patients with subclinical hypothyroidism and/or positive TPO-antibodies, differences in serum TSH were similar, but not statistically significant anymore. Serum $\mathrm{FT}_{4}$ values were similar in the various genotypes.

No association was found between the DII polymorphism and response rate (RR of subjects with the DII polymorphism compared to wild type: 0.84 , CI $0.54-1.31$ in heterozygous patients and $\mathrm{RR}=0.96$, CI $0.45-2.02$ in homozygous patients) (Table 5).

\section{Discussion}

Our finding that higher $\mathrm{TSH}$, but not $\mathrm{FT}_{4}$, is related to response, is in agreement with studies measuring evening TSH concentrations $(6,28)$. Other studies measuring TSH in the morning did not find such a relation (8-12). We only found a significant association after exclusion of patients with positive TPO titers. Since other studies analyzing morning TSH in relation to

Table 3 Treatment response per tertile of HPT-axis parameter, biochemical thyroid abnormalities excluded.

\begin{tabular}{|c|c|c|c|c|c|c|c|c|}
\hline & & $N$ & $\begin{array}{c}\text { Value of } \\
\text { parameter } \\
\text { median (range) }\end{array}$ & $\begin{array}{c}\text { HRSD at } \\
\text { baseline } \\
\text { (mean } \pm \text { S.D.) }\end{array}$ & $\begin{array}{c}\text { Decrease in } \\
\text { HRSD } \\
\text { (mean } \pm \text { s.D.) }\end{array}$ & $\begin{array}{l}\text { Response } \\
\text { rate } n(\%)\end{array}$ & $\begin{array}{l}\text { Relative } \\
\text { response } \\
\text { rate }\end{array}$ & $95 \% \mathrm{Cl}$ \\
\hline \multirow[t]{3}{*}{ Serum TSH ${ }^{\mathrm{a}} \mathrm{mU} / \mathrm{l}$} & low & 28 & $1.20(0.49-1.50)$ & $20 \pm 3$ & $7 \pm 6$ & $10(36 \%)$ & 1.00 & \\
\hline & middle & 24 & $1.75(1.60-2.10)$ & $21 \pm 4$ & $10 \pm 6$ & $10(42 \%)$ & 1.17 & $0.59-2.30$ \\
\hline & high & 30 & $2.50(2.20-3.70)$ & $22 \pm 4$ & $12 \pm 6$ & $20(67 \%)$ & 1.87 & $1.07-3.26$ \\
\hline \multirow{3}{*}{ Serum $\mathrm{FT}_{4}{ }^{\mathrm{a}} \mathrm{pmol} / \mathrm{l}$} & low & 28 & $11.7(9.2-12.5)$ & $21 \pm 3$ & $10 \pm 6$ & $14(50 \%)$ & 1.00 & \\
\hline & middle & 26 & $13.8(12.7-15.1)$ & $21 \pm 4$ & $11 \pm 6$ & $17(65 \%)$ & 1.31 & $0.82-2.08$ \\
\hline & high & 28 & $16.3(15.2-18.7)$ & $21 \pm 4$ & $7 \pm 7$ & $9(32 \%)$ & 0.73 & $0.38-1.43$ \\
\hline \multirow[t]{3}{*}{ Delta TSH ${ }^{\mathrm{b}} \mathrm{mU} / \mathrm{l}$} & low & 27 & $6.70(1.52-8.55)$ & $20 \pm 3$ & $9 \pm 7$ & $14(52 \%)$ & 1.00 & \\
\hline & middle & 28 & $10.93(8.85-12.80)$ & $21 \pm 3$ & $10 \pm 6$ & $13(46 \%)$ & 0.90 & $0.52-1.53$ \\
\hline & high & 27 & $16.03(13.00-24.98)$ & $21 \pm 4$ & $9 \pm 7$ & $13(48 \%)$ & 0.93 & $0.54-1.58$ \\
\hline
\end{tabular}

Per HPT-axis parameter, patients $(n=82)$ are divided in three equal groups (tertiles) after exclusion of patients with subclinical hypothyroidism (TSH $>4.00$ mU/l, $n=10)$ and/or positive TPO antibodies $(n=9)$. Response rates are shown per tertile.

${ }^{a}$ Morning hormone values measured before dexamethasone ingestion.

${ }^{\mathrm{b}}$ The absolute increase in TSH concentration after i.v. injection of $400 \mu \mathrm{g} \mathrm{TRH}$ and $100 \mu \mathrm{g} \mathrm{CRH}$. Patients had ingested $1.5 \mathrm{mg}$ dexamethasone the evening before testing (modified DEX/CRH test, Heuser et al.(24)). 
Table 4 Clinical characteristics according to DII genotype.

\begin{tabular}{|c|c|c|c|}
\hline & AA (wild type) $n=44$ & AG (heterozygous) $n=41$ & GG (homozygous) $n=8$ \\
\hline Age (mean \pm s.D.) & $46 \pm 11$ & $48 \pm 11$ & $46 \pm 11$ \\
\hline Woman $(n, \%)$ & $28(64 \%)$ & $25(61 \%)$ & $5(63 \%)$ \\
\hline Chronic depression $(n, \%)$ & $20(46 \%)$ & $18(44 \%)$ & $3(38 \%)$ \\
\hline Therapy resistant ${ }^{*}(n, \%)$ & $19(43 \%)$ & $13(32 \%)$ & $3(38 \%)$ \\
\hline TSH mU// ${ }^{\text {a† }}$ (median, $P^{10}-P^{90}$ ) & $2.30(1.10-4.35)$ & $1.70(0.90-2.78)$ & $1.95(1.40-7.00)$ \\
\hline $\mathrm{FT}_{4} \mathrm{pmol} / /^{\mathrm{a}}$ (mean \pm S.D. $)$ & $13.5 \pm 2.1$ & $14.2 \pm 2.1$ & $12.9 \pm 1.3$ \\
\hline Delta TSH mU// ${ }^{\text {b‡ }}\left(\right.$ median, $\left.P^{10}-P^{90}\right)$ & $12.55(6.13-25.54)$ & $10.00(4.88-17.16)$ & $13.25(6.09-35.80)$ \\
\hline
\end{tabular}

*Therapy resistance was defined as having a score of 1 or more in the Thase and Rush classification for therapy resistance (39).

${ }^{a}$ Morning hormone values measured before dexamethasone ingestion.

${ }^{\mathrm{b}}$ The absolute increase of TSH after i.v. injection of $400 \mu \mathrm{g} \mathrm{TRH}$ and $100 \mu \mathrm{g} \mathrm{CRH}$. Patients had ingested $1.5 \mathrm{mg}$ dexamethasone the evening before testing (modified DEX/CRH test, Heuser et al. (24)).

${ }^{\dagger}$ Serum TSH values were significantly different between the three genotypes $(\mathrm{F}=4.00, \mathrm{df}=2,90, P=0.02)$. Post-hoc tests revealed that the serum TSH difference between the AA genotype and heterozygous patients was significant $(P=0.01,95 \% \mathrm{Cl}$ : $0.03-0.22)$.

${ }^{\ddagger}$ Delta TSH was significantly different between the three genotypes $(\mathrm{F}=3.08, \mathrm{df}=2,90, P=0.05)$. Post-hoc tests revealed that the delta TSH difference between the AA genotype and heterozygous patients was significant $(P=0.03,95 \% \mathrm{Cl}: 0.02-0.23)$.

response did not assess TPO antibodies, this may explain some of the discrepancies in the literature.

The positive association between TSH and treatment response could not be attributed to $\mathrm{T}_{3}$ treatment, since $\mathrm{T}_{3}$-treatment was not a determinant of response in a logistic regression model. Furthermore, the exclusion of patients with subclinical hypothyroidism or positive TPO antibodies eliminates patients who might benefit from the $\mathrm{T}_{3}$ treatment.

To explain the relation between TSH and treatment response is a matter of speculation. The often described hypercortisolism in depressed patients may induce lower serum TSH and indicate treatment resistant depression (29). However, as we described earlier, in this population low TSH was not related to high 24hour urinary cortisol levels (30). Another explanation is that a relatively low TSH is due to relatively low TRH. Indeed, the expression of TRH in the hypothalamus of depressed patients as compared to control patients is decreased (31). Since TRH is influenced by serotonin in the rat brain (32), serum TSH concentrations may reflect a disturbed serotonin system.

The effect that TPO antibodies have on the relation between TSH and response can be explained by two factors. First, TPO antibodies are a first sign of thyroid autoimmune disease leading to increased TSH concentrations (13). TPO antibodies may, as a peripheral determinant of TSH concentration, obscure the proper relation between TSH and response. Second, TPO antibody positivity itself may be a (negative) determinant of response. Because of the low prevalence of patients with a positive TPO antibody titer in our study, we could not address this hypothesis. Some indication of the importance of TPO antibodies was given by a study wherein the presence of TPO-antibodies in the first trimester of pregnancy, but not subclinical hypothyroidism per se, predicted postpartum depression (33). A recent study described that the presence of Thyroid Binding Inhibitory Immunoglobulins was related to treatment non-response in depressed patients (34). These findings support an association between the immune system and depression.

With respect to the TRH-test, one large study $(n=$ 105) found that high delta TSH predicted treatment non-response (7), while in a number of smaller studies this association was confirmed but also contradicted $(6,35,36)$. In the present study, delta TSH did not predict response. An explanation for this discrepancy may be the dexamethasone pre-treatment in our study, since glucocorticoids suppress serum TSH (37).

The prevalence of the DII genotypes in the present study was comparable with that of a population of 156 healthy, Dutch blood donors $(48 \%$ heterozygous and $15 \%$ homozygous subjects) (21). The age (46-yearsold), but not the gender ( $35 \%$ females), of these subjects was similar to our patients. Despite the association between the DII polymorphism and serum TSH, this did not result in a prediction of response by the DII polymorphism. The present and the study by Peeters et al. (21) found that serum TSH in heterozygous subjects was lower than in the wild-type and homozygous subjects. This odd, but replicable observation

Table 5 Treatment response according to DII genotype.

\begin{tabular}{lccccrr}
\hline & $\begin{array}{c}\mathbf{N} \\
\text { total } \mathrm{n}=93\end{array}$ & $\begin{array}{c}\text { HRSD at baseline } \\
(\text { mean } \pm \text { s.D.) }\end{array}$ & $\begin{array}{c}\text { Decrease in HRSD } \\
\text { (mean } \pm \text { s.D.) }\end{array}$ & $\begin{array}{c}\text { Response rate } \\
\mathrm{n}(\%)\end{array}$ & $\begin{array}{c}\text { Relative } \\
\text { response rate }\end{array}$ & \begin{tabular}{c} 
95\% Cl \\
\hline AA (wild type)
\end{tabular} \\
AG (heterozygous) & 44 & $20 \pm 3$ & $10 \pm 6$ & $23(52 \%)$ & \\
GG (homozygous) & 81 & $21 \pm 4$ & $10 \pm 7$ & $18(44 \%)$ & 0.84 & $0.54-1.31$ \\
\hline
\end{tabular}

Patients $(n=93)$ are divided in groups according to DIl genotype (AA = wild type, AG = heterozygous, $\mathrm{GG}=$ homozygous). Response rates are shown per genotype. 
may be explained by a hypothesis that part of DII proteins form dimers (of both alleles) (38). Speculating on this, heterodimers of DII proteins, one with the polymorphism and one without, may have higher catalytical activity than homodimers that will result in higher $\mathrm{T}_{3}$ concentrations in the anterior pituitary to suppress TSH.

Compared to other studies, we investigated a larger population of depressed patients and we investigated the predictive value of HPT-axis parameters prospectively after correction for TPO antibodies. These patients had been free of antidepressants for three months. Influence of previous treatments on baseline parameters was therefore unlikely. In this setting, higher serum TSH was significantly related to response rates after the exclusion of patients with positive TPO antibodies. Therefore, we recommend that in future studies, TPO antibodies should be included in studies on the prediction of antidepressant response.

\section{Acknowledgements}

Paroxetine (Seroxat) and $\mathrm{T}_{3}$ (Cytomel) were kindly supplied by Smith Kline Beecham. Serum cortisol and ACTH were measured in the Endocrinology Laboratory of the AMC under supervision of E. Endert.

\section{References}

1 Kornstein SG \& Schneider RK. Clinical features of treatmentresistant depression. Journal of Clinical Psychiatry 200162 Suppl $1618-25$.

2 Pop VJ, Maartens LH, Leusink G et al. Are autoimmune thyroid dysfunction and depression related? Journal of Clinical Endocrinology and Metabolism 1998 83(9) 3194-3197.

3 Nemeroff CB, Simon JS, Haggerty JJ, Jr \& Evans DL. Antithyroid antibodies in depressed patients. American Journal of Psychiatry 1985 142(7) 840-843.

4 Jackson IM \& Luo LG. Antidepressants inhibit the glucocorticoid stimulation of thyrotropin releasing hormone expression in cultured hypothalamic neurons. Journal of Investigative Medicine 1998 46(9) 470-474.

5 Kirkegaard C \& Faber J. The role of thyroid hormones in depression. European Journal of Endocrinology 1998 138(1) 1-9.

6 Duval F, Mokrani MC, Crocq MA, Jautz M, Barley P, Diep TS \& Macher JP. Effect of antidepressant medication on morning and evening thyroid function tests during a major depressive episode. Archives of General Psychiatry 1996 53(9) 833-840.

7 Sullivan PF, Wilson DA, Mulder RT \& Joyce PR. The hypothalamicpituitary-thyroid axis in major depression. Acta Psychiatrica Scandinavia 1997 95(5) 370-378.

8 Fava M, Labbate LA, Abraham ME \& Rosenbaum JF. Hypothyroidism and hyperthyroidism in major depression revisited. Journal of Clinical Psychiatry 1995 56(5) 186-192.

9 Sokolov ST, Kutcher SP \& Joffe RT. Changes in thyroid hormone levels associated with desipramine response in adolescent depression. Progress in Neuropsychopharmacology Biology and Psychiatry 1996 20(6) 1053-1063.
10 Rao ML, Ruhrmann S, Retey B, Liappis N, Fuger J, Kraemer M, Kasper S \& Moller HJ. Low plasma thyroid indices of depressed patients are attenuated by antidepressant drugs and influence treatment outcome. Pharmacopsychiatry 1996 29(5) 180-186.

11 Baumgartner A, Graf KJ, Kurten I \& Meinhold H. The hypothalamic-pituitary-thyroid axis in psychiatric patients and healthy subjects: Parts 1-4. Psychiatry Research 1988 24(3) 271-332.

12 Hoflich G, Kasper S, Danos P \& Schmidt R. Thyroid hormones, body temperature, and antidepressant treatment. Biological Psychiatry 1992 31(8) 859-862.

13 Strieder TG, Prummel MF, Tijssen JG, Endert E \& Wiersinga WM. Risk factors for and prevalence of thyroid disorders in a crosssectional study among healthy female relatives of patients with autoimmune thyroid disease. Clinical Endocrinology (Oxf) 2003 59(3) 396-401.

14 Bianco AC, Salvatore D, Gereben B, Berry MJ \& Larsen PR. Biochemistry, cellular and molecular biology, and physiological roles of the iodothyronine selenodeiodinases. Endocrine Reviews 200223 (1) 38-89.

15 Eravci M, Pinna G, Meinhold H \& Baumgartner A. Effects of pharmacological and nonpharmacological treatments on thyroid hormone metabolism and concentrations in rat brain. Endocrinology 2000 141(3) 1027-1040.

16 Baumgartner A, Dubeyko M, Campos-Barros A, Eravci M \& Meinhold H. Subchronic administration of fluoxetine to rats affects triiodothyronine production and deiodination in regions of the cortex and in the limbic forebrain. Brain Research 1994 635(1-2) 68-74.

17 Campos-Barros A, Meinhold H, Stula M, Muller F, Kohler R, Eravci M, Putzien $O$ \& Baumgartner A. The influence of desipramine on thyroid hormone metabolism in rat brain. Journal of Pharmacology and Experimental Therapeutics 1994 268(3) 1143-1152.

18 Atterwill CK. Effect of acute and chronic tri-iodothyronine (T3) administration to rats on central 5-HT and dopamine-mediated behavioural responses and related brain biochemistry. Neuropharmacology 1981 20(2) 131-144.

19 Schneider MJ, Fiering SN, Pallud SE, Parlow AF, St Germain DL \& Galton VA. Targeted disruption of the type 2 selenodeiodinase gene (DIO2) results in a phenotype of pituitary resistance to $\mathrm{T}_{4}$. Molecular Endocrinology 2001 15(12) 2137-2148.

20 Mentuccia D, Proietti-Pannunzi L, Tanner K, Bacci V, Pollin TI, Poehlman ET, Shuldiner AR \& Celi FS. Association between a novel variant of the human type 2 deiodinase gene Thr92Ala and insulin resistance: evidence of interaction with the Trp64Arg variant of the beta-3-adrenergic receptor. Diabetes 2002 51(3) 880-883.

21 Peeters RP, van Toor H, Klootwijk W, de Rijke YB, Kuiper GG, Uitterlinden AG \& Visser TJ. Polymorphisms in thyroid hormone pathway genes are associated with plasma TSH and iodothyronine levels in healthy subjects. Journal of Clinical Endocrinology and Metabolism 2003 88(6) 2880-2888.

22 Appelhof BC, Brouwer JP, Van Dyck R, Fliers E, Hoogendijk WJ, Huyser J, Schene AH, Tijssen JG \& Wiersinga WM. Triiodothyronine addition to paroxetine in the treatment of major depressive disorder. Journal of Clinical Endocrinology and Metabolism 2004 89(12) 6271-6276.

23 Diagnostic and Statistical Manual of Mental Disorders. 4th edn:DSM-IV. ed. Washington, D.C: American Psychiatric Association, 1994.

24 Heuser I, Yassouridis A \& Holsboer F. The combined dexamethasone/CRH test: a refined laboratory test for psychiatric disorders. Journal of Psychiatric Research 1994 28(4) 341-356.

25 Rush AJ, Giles DE, Schlesser MA, Orsolak PJ, Weissenburger JE, Folton CL, Fairchild CJ \& Roffwarg HP. Dexamethasone response, thyrotropin-releasing hormone stimulation, rapid eye movement latency, and subtypes of depression. Biological Psychiatry 1997 41(9) 915-928. 
26 Hofmann PJ, Nutzinger DO, Kotter MR \& Herzog G. The hypothalamic-pituitary-thyroid axis in agoraphobia, panic disorder, major depression and normal controls. Journal of Affective Disorders 2001 66(1) 75-77.

27 Wiersinga WM. The interpretation of the thyroid stimulating hormone (TSH) assay. Nederlands Tijdschrift voor Geneeskunde 2003 147(24) 1156-1158.

28 Orth DN, Shelton RC, Nicholson WE, Beck-Peccoz P, Tomarken AJ, Persani L \& Loosen PT. Serum thyrotropin concentrations and bioactivity during sleep deprivation in depression. Archives of General Psychiatry 2001 58(1) 77-83.

29 Jackson IM. The thyroid axis and depression. Thyroid $1998 \mathbf{8}(10)$ 951-956.

30 Brouwer JP, Appelhof BC, Hoogendijk WJ, Huyser J, Endert E, Zuketto C, Schene AH, Tijssen JG, van Dyok R, Wiersinga WM \& Fliers E. Thyroid and adrenal axis in major depression: a controlled study in outpatients. European Journal of Endocrinology 2005 $152(2)$ 185-191.

31 Alkemade A, Unmehopa UA, Brouwer JP, Hoogendijk WJ, Wiersinga WM, Swaab DF \& Fliers E. Decreased thyrotropinreleasing hormone gene expression in the hypothalamic paraventricular nucleus of patients with major depression. Molecular Psychiatry 2003 8(10) 838-839.

32 Morley JE. Neuroendocrine control of thyrotropin secretion. Endocrine Reviews 1981 2(4) 396-436.

33 Kuijpens JL, Vader HL, Drexhage HA, Wiersinga WM, van Son MJ \& Pop VJ. Thyroid peroxidase antibodies during gestation are a marker for subsequent depression postpartum. European Journal of Endocrinology 2001 145(5) 579-584.
34 Fountoulakis KN, Iacovides A, Grammaticos P, St Kaprinis G \& Bech P. Thyroid function in clinical subtypes of major depression: an exploratory study. BMC Psychiatry 2004 4(1) 6.

35 Langer G, Koinig G, Hatzinger R, Hatzinger R, Schonbeck G, Resch F, Aschauer H, Keshavan MS \& Sieghart W. Response of thyrotropin to thyrotropin-releasing hormone as predictor of treatment outcome, Prediction of recovery and relapse in treatment with antidepressants and neuroleptics. Archives of General Psychiatry $1986 \mathbf{4 3}(9)$ 861-868.

36 Targum SD. The application of serial neuroendocrine challenge studies in the management of depressive disorder. Biological Psychiatry 1983 18(1) 3-19.

37 Re RN, Kourides IA, Ridgway EC, Weintraub BD \& Maloof F. The effect of glucocorticoid administration on human pituitary secretion of thyrotropin and prolactin. Journal of Clinical Endocrinology and Metabolism 1976 43(2) 338-346.

38 Curcio-Morelli C, Gereben B, Zavacki AM, Kim BW, Huang S, Harney JW, Larsen PR \& Bianco AC. In vivo dimerization of types 1, 2, and 3 iodothyronine selenodeiodinases. Endocrinology 2003 144(3) 937-946.

39 Thase ME \& Rush AJ. When at first you don't succeed: sequential strategies for antidepressant nonresponders. Journal of Clinical Psychiatry 1997 58(Suppl 13) 23-29.

Received 26 November 2005

Accepted 1 March 2006 